\title{
BREUKER, Remco E. Establishing a Pluralist Society in Medieval Korea, 918-1170: History, Ideology and Identity in the Koryo Dynasty. Leiden, Netherland: Brill, 2010, xvi+484 pp.
}

Hyung-Wook Kim*

The issue of pluralism in society is a complicated subject, requiring an even more cautious approach if the society in question is from the premodern period. Although the issue of "diversity" has been raised and discussed lately amidst the conflict found in various elements of society, relatively few research studies have focused on this issue in pre-modern history. Meanwhile, the Chosŏn Dynasty (1392-1910) ${ }^{1}$ remains the main subject of pre-modern Korean history research among scholars outside Korea. Koryŏ (918-1392), the previous dynasty, is relatively less discussed despite its historical importance. Remco E. Breuker ${ }^{2}$ s work is valuable to understanding the Koryŏ dynasty, and his book certainly illuminates an intriguing feature of this state-pluralism.

According to the author, Koryŏ remained a thoroughly pluralist society even after the unification of the peninsula, and was far from a simple society where a specific ideology or characteristic such as Confucianism,

\footnotetext{
* Visiting Scholar, Center for Korean Studies, UCLA
}

1 Chosŏn, facing foreign aggression, changed its name to the Taehan Empire in 1897.

2 Breuker, a professor at Leiden University in the Netherlands, has published many articles on Koryŏ, a medieval state in Korean history, and has expanded his research on northeast Asia to include Manchuria, which he mentions in this book as well, in terms of Koryŏ's foreign policies and relationships. 
Buddhism, or Daoism prevailed. Open-mindedness with a keen awareness of reality based on the practicality of the Koryŏ literati was a major factor that enabled Koryŏ not only to flourish but also to overcome a series of Liao invasions by the Khitans from the late tenth through the eleventh century.

To articulate his assertion that Koryŏ society was dynamic and incorporated multiple ideologies and diverse beliefs such as Neo-Confucianism, Buddhism, and Daoism rather than remaining monistic, Breuker divides this book into three parts. In the first part, "Establishment of a Pluralist Community," he lays out four different themes that he believes constitute "the backbone" of Koryŏ as a historical society-collective names and designations, a historic territory, shared idea of descent, and legitimation. In the first chapter, Breuker explains various terms used when referring to Koryŏ, such as Samhan, Haedong, Tongbang, Tongguk, and Ch'ŏnggu, stating that Samhan, literally meaning 'three Han' was mainly used as a domestic reference while putting the rest of the terms in contrast with foreign political entities, mostly those in China. Breuker notes Samhan (Three Han) as the charter polity on Korean peninsula. Samhan again plays an important role in gaining an understanding of Koryŏ's historic territory in the second chapter. In spite of questions on the precise boundaries of the ancestral land of the Korean people, Koryǒ's literati did not show any hesitation in considering the old Koguryŏ territory as theirs, as Koguryŏ had been part of the Samhan heritage, and consequently, the notion of the Samhan transcended boundaries in collective thought among the Koryŏ literati. In the third chapter, Breuker examines the Dynastic Genealogy of Koryo and the History of the Three Kingdoms as emphasizing shared ideas of descent shown in their texts, where people of Koryŏ were called the people of Samhan while introducing Kija, Tan'gun, and King Tongmyŏng, as founding fathers of Koryŏ. He argues that these many complexities and competing narratives of origin are certainly examples proving the plurality of Koryŏ society. Breuker concludes the first part with the fourth chapter on legitimation. Here again, he emphasizes the notion of Samhan as introducing contemporary scholarship that either 
underlines one specific legacy (from Koguryŏ or Silla) or dual successionism. By stressing Samhan successionism instead of putting emphasis on either Koguryŏ or Silla, he once again claims that Samhan constituted the background of Koryŏ's historical identity, eventually resulting in the flourishing of pluralism in Koryo from the time of its establishment in the tenth century.

In the book's second part, the author analyzes in detail pluralistic features in Koryŏ society. Since the king and scholar-officials were two main figures in supervising and exercising various policies in Koryŏ until 1170, when military officials seized political power through a coup d'état, Breuker explains Koryŏ's pluralism through an analysis of the king as the most important focal point of its society, and the literati as an illustration proving the prevalence of pluralist thought in Koryŏ. In chapter five, he examines Koryǒ's rulers from two different aspects-as nominal head of the bureaucracy and their active participation in the administration. Although classical Confucian thought remained strong regarding the status of the ruler throughout the Koryŏ dynasty, other thoughts such as Buddhism (or Daoism) were not overlooked by the kings and literati, as shown in their observance of the Assembly of the Eight Prohibitions and the Lantern Festival. Since these events and rituals were useful to maintain order and peace in society, the Koryŏ ruler relied on Confucian, Buddhist, and Daoist state rituals and on worship related to local indigenous geographical features. Koryǒ's foreign relations also reveal its pluralistic nature in its cultural, historical, or economic ties to neighboring states. As meticulously examined in chapter six, Koryǒ's foreign relations were far from simple. By examining Koryŏ's policies toward the Liao, Jin, and Song, Breaker illustrates the error of calling its relations "cordial with Song, hostile toward Liao and Jin." According to the author, Koryŏ always prioritized its own interests, which in fact allowed them to contact "barbarian" states such as the Liao and Jin rather than the "civilized" Song, due to prevailing pluralism in the society. Chapter seven shows how Daoism, Buddhism, and Confucianism were all able to flourish in the same period through various writings of Koryŏ literati who did not express much re- 
sistance to the idea of leaving contradictions unsolved. They were neither extreme Confucians, nor were they die-hard Buddhists. This flexibility among Koryŏ literati is also revealed in the fact that Koryŏ policymakers were neither Sino-centric nor unprincipled in favor of usurping royal prerogatives. In chapter eight, Breuker attributes Koryŏ's pluralism to specific and contingent historical circumstances. In Koryŏ, several kinds of logic - Confucian, Buddhist thought, and the indigenous system - were in constant conflict, which eventually made it necessary to find a way to coexist, both on a social and an individual level. Koryŏ's geographical location between Manchuria and the Chinese mainland also explains Koryŏ's pluralist worldview because of the presence of two different civilizations, emphasizing how the differing values of these civilizations pushed Koryŏ to adopt an ever-changing view of the world. This provides some explanation as to why the rise of the Mongol Empire was to blame for the decrease (if not demise) of the pluralist view in Koryŏ after the late thirteenth century.

In the last part of the book, composed of three chapters, Breuker shows how pluralist ideology was used in reality for practical purposes by taking examples of the compilation of the Histories of the Three Kingdoms, discussion of the Ten Injunctions, and examination of Myoch'ŏng's revolt. In chapter nine, he illustrates why Kim Pu-sik's History of the Three Kingdoms has been criticized since its publication due to the present situation of critiques showing that Kwŏn Kŭn and Sin Ch'ae-ho attacked Kim Pu-sik and his work for opposite reasons, about five hundred years apart from each other, though Kim merely furnished his state with astonishing ideological flexibility, proving distinctive plurality in Koryŏ society. Breuker gives another example in chapter ten in order to emphasize pluralism in Koryŏ: the Ten Injunctions, the royal instructions by King T'aejo, recorded in the History of Koryŏ. Strongly suggesting that it was invented in the eleventh century during King Hyŏnjong's reign, Breuker points out features related to Confucianism, Buddhism, Daoism, and nativist thought from each injunction, which consequently contain many ambiguities_-proof of pluralism — instead of removing them rationally 
from its contents. In the last chapter, Breuker provides a very interesting perspective on the Myoch'ŏng revolt. Unlike traditional scholarship, in which Myoch'ŏng's revolt was understood as a clash between a Sinocentric group in Kaegyŏng, represented by Kim Pu-sik, and the Sŏgyŏng group that was inspired with a fully independent spirit, led by Myoch'ŏng and Chŏng Chi-sang, Breuker argues that Myoch'ŏng's revolt was an unsuccessful attempt to negate Koryŏ's pluralism, suppressed by the literati group with an already prevailing pluralist world view.

It is worthwhile to note that the author first properly points out the difference between a pluralist world view and a relativist world view by explaining that the former acknowledges the possibility of fundamental differences and allows them to coexist while the latter does not recognize any difference. Because his main argument focuses on showing pluralism in Koryŏ's society, it is crucial to understand the exact meaning and characteristics of "pluralism/-ist" as he lays them out. It is also fascinating to note the range of materials he draws upon to make his arguments throughout this book. Not only providing comprehensive works for a theoretical frame at the beginning, he also examines various sources from Korea, China, and Japan. He first thoughtfully explains that writing history is always closely related to present-day affairs, arguing that the excessive dichotomization of Koryŏ society without examining its validity is also an outcome of socio-political situations at the time that research was conducted in the later periods. Breuker claims Sin Ch'ae-ho's early twentieth century evaluation of Myoch'ŏng's revolt is one example specifically displaying the influence of the present on writing about the past. Although I understand that Breuker focuses on illuminating plurality in the first half of the Koryŏ dynasty until the military coup d'état in 1170, his claim that projection upon the past is not completely free from present issues and often heavily influenced by them is equally important because it is one of the reasons that keeps people from recognizing the prominence of pluralism in Koryo society. I strongly believe that many of the important points he argues would be understood better with a recognition of the links between the present reality and publishing historical docu- 
ments.

It is refreshing and convincing for Breuker to bring out the concept of Samhan and charter polity as an early expression of collective identity and possible nationalism in Korean history. Although his argument certainly presents a valid point on the existence of a pristine form of nationalism as early as the tenth through the thirteenth centuries in Korea, it should not be overlooked that the involvement of the common people is one of the most important points in the discourse on constructing a nation and nationalism. It is obvious that Samhan played a crucial role in the emergence of a collective identity among the Koryŏ rulers and literati, as Breuker convincingly portrays. However, few records or occasions, if any, reveal that the common people also held a strong awareness of themselves as people of Samhan in the same way that Koryŏ's literati did. Although it is extremely difficult to examine the common people's thoughts due to a lack of materials, it is questionable whether the terms nation/nationalism can be used in a premodern context without any clarification. Breuker also comprehensively examines the History of Three Kingdoms as illustrating the society's pluralistic features and saving it from unfair criticism by people in later periods, specifically, Sin Ch'ae-ho. Although I agree with Breuker's argument regarding his evaluation and analysis of the History of the Three Kingdoms, it is a little strange that he mentions very briefly, in precisely one sentence, Kim's exclusion of Parhae. Considering that Kim Pu-sik could have displayed plurality in Koryŏ even more by including Parhae in its history, it would have been appropriate if Breuker had expressed his thoughts on Parhae's conspicuous absence from Kim's History of the Three Kingdoms.

Breuker's book presents an insightful analysis, indeed, on Koryŏ society, which has been rather neglected in research on Korean history. It is even more difficult to find material written in English regarding this premodern state. His research has certainly contributed to the search for the roots of a modern nation in the premodern period. His notion of diversity and pluralism in the early Koryŏ period from the first part of the tenth century through the twelfth century has us pondering the many serious 
issues we are facing, such as escalating extremism and clashes between different cultures due to the ignorance of "others." 
